\title{
Cirkónium-dioxid használata a klinikai gyakorlatban
}

\author{
Esetismertetés
}

DR. SOMFAI DÓRA, DR. ZSIGMOND ÁGNES, DR. KÁROLYHÁZY KATALIN, DR. KISPÉLYI BARBARA, DR. HERMANN PÉTER

\begin{abstract}
A cirkónium-dioxid kiváló fizikai, mechanikai és esztétikai tulajdonságai miatt a fémmentes fogpótlások közül ma is az egyik legnépszerübb anyag, mely az esetek jelentős részében a hagyományos fémkerámia kiváltására is szolgálhat. A napjainkban egyre inkább teret hódító CAD/CAM technológia segítségével készülhetnek el. Cikkünkben három esetbemutatáson keresztül ismertetjük a cirkónium-dioxid mindennapi fogorvosi gyakorlatban való felhasználhatóságát.
\end{abstract}

Kulcsszavak: cirkónium-dioxid, esztétika, CAD/CAM, diagnosztikus felviaszolás

A cirkónium a periódusos rendszerben 40 -es rendszámmal megtalálható tetragonális szerkezetű fém. A természetben tiszta állapotban azonban nem lelhető fel, hanem vagy szilikátoxiddal együtt, vagy szabad oxidként található meg, tartalmaz ezenkívül még radioaktív anyagokat, illetve egyéb fémeket is. Ebben a formájában sem az iparban, sem a fogászatban nem használják. A cikrónium-dioxid, melyet viszont széles körben alkalmaznak, a fent említett cirkónium egy hoszszú és körülményes tisztítási eljárás során nyert formája, amit különböző oxidokkal $\left(\mathrm{MgO}_{2}, \mathrm{Y}_{2} \mathrm{O}_{3}\right)$ stabilizálnak. Cirkónium-dioxidot előállíthatnak cirkonhomokból vagy cirkonföldböl, amit a világon sok helyen bányásznak. A gyógyászat számos területén használatos (csípőprotézisek, implantátumfejek, híd- és korona váz), de csak nagy tisztaságú, radioaktív anyagoktól megfosztott formában.

A cirkónium-dioxid fogászati felhasználása a fogászat területén a 90-es években indult útjára. Napjaink fogorvosi gyakorlatában a cirkónium-dioxid vázú, kerámia leplezésű restaurációk kiválthatják a klasszikus fémkerámia rögzített pótlásokat. Fehér színük miatt előnyösebbek az optikai tulajdonságaik, mint a hagyományos fémkerámiának, így sok helyen "fémmentes" fogpótlásként említik őket. Fontos megjegyezni, hogy míg a klasszikus porcelángyártás alapanyaga a kaolin, a földpát és a kvarc, addig a porcelán fogászatban használatos változata nem, vagy csak nagyon kis százalékban tartalmaz kaolint, ezért ezt az anyagot fogászati kerámiának nevezzük.

Biokompatibilis, lágyszövetekhez való viszonya a teljeskerámiákéhoz hasonló, azonban míg más teljeskerámiákat leginkább a frontterületen szólókoronák, illetve maximum háromtagú restaurációk készítéséhez javasolják, addig a cirkónium-dioxid vázas fogmüvek szélesebb indikációs területen alkalmazhatók. Megfelelő fizikai tulajdonságaik miatt nagyobb kiterjedésű hidak, sínek készítése sem akadály [1,2, 3]. Egyes irodalmi források szerint akár szabad végú hídpótlás is készíthető [4], mivel kiemelkedően magas a torziós ellenállása [5]. További előnyös tulajdonságuk, hogy kiváló hőszigetelésük miatt a preparált fogak szenzitivitása csökkenthető. A váz színe igazítható a csonk színéhez, így jobb esztétikai eredmény érhető el. Opacitása miatt az elszíneződött gyökérkezelt fogak, illetve akár fémből készült csapok is szépen leplezhetők [6]. Radiopac tulajdonsága miatt röntgenfelvételen való kontrollálhatósága kiváló, jól ellenőrizhető például a széli záródás vonala. Általános preparálási javaslat a cirkónium-dioxid vázas fogmúvek esetében, hogy az axiális falakon 1,2 mm-t, a centrális barázdában 1,5 mm-t míg az inciziális él és a funkciós csücskök területén $2 \mathrm{~mm}$-t kell elvenni [7]. A fogak szupra- és szubgingivális előkészítése mellett egyaránt alkalmazható. A nemzetközi irodalom a chamfer vagy legömbölyített vállas preparációt tartja elönyösnek a tangencionális preparálással szemben [8]. Egy 2012-es in vitro tanulmány szerint a váll alakja semmilyen hatással nincs a cirkónium-dioxid vázas koronák sérülésére, nem befolyásolja azok anyagfáradását, illetve élettartamát. További előnyös tulajdonság ezért, hogy a preparálási formát a pillérfog aktuális klinikai állapota szerint választhatjuk meg [9]. A témával foglalkozó cikkek többsége szerint restaurációk beragasztására üvegionomer-cementet, foszfátcementet és rezin cementeket egyaránt alkalmazhatunk $[10,11]$. A cirkónium-dioxid megmunkálása hideg frézeléssel történhet, ami a napjainkban egyre nagyobb teret hódító CAD/CAM technológiához kapcsolható. 
A kerámia leplezésú cirkónium-doxid vázas fix fogmúvek mindennapi fogorvosi gyakorlatban való alkalmazását az alábbi három esetbemutatás ismerteti.

\section{1. eset}

45 éves hölgy páciens, krónikus fogágybetegsége miatt rendszeres parodontológiai kezelés alatt áll. Jobb felső kettes, fogíven kívül álló csapfogát előzetesen eltávolították (1.1. ábra). A jobb felső egyes és hármas fog közötti rövid meziodisztális távolság miatt a foghiány pótlása implantátummal nem volt lehetséges. Mivel a 11-es fog teljesen ép volt, de a 14-es fog kompozit töméssel ellátott, illetve a 13-as fog gyökérkezelt, így a 12-es fogának restaurációjára az alábbi kezelési tervet választottuk: 3 tagú, cirkónium-dioxid vázú, kerámia leplezésű fogpótlás meziálisan szabad véggel. Leplezett horgonykoronák: 14 és 13.

A páciens jobb felső hármas foga 15 éve gyökérkezelt, a gyökértömés faláló, csúcsig érő, panaszmentes, ezért ennek cseréje nem volt indokolt. A 13-as fog nagy része viszont kompozittal volt felépítve, tehát a majdan rákerülő fogpótlás megfelelő szerkezeti tartósságának érdekében adhezív üvegszálas csappal láttuk el. Azért, hogy a páciens számára szemléltethető legyen a majdani fogpótlás, illetve meggyőződjünk arról, hogy kezelési tervünk esztétikai szempontból megfelelő lesz, a fogtechnikai labortól diagnosztikus felviaszolást kértünk.

A páciens magas esztétikai igénye miatt mindenképp valamilyen fémmentes megoldásban gondolkodtunk. A cirkónium-dioxid vázas fogpótlások torziós ellenállása 900-1100 MPa között van [12], nyomási szilárdsága 2000 Mpa [13] körüli, ami a fogászati kerámiák között kiemelkedően magas. Jelen esetben a kimagasló esztétikai igények, a szabad vég, illetve a fogpótlás hoszsza miatt a cirkónium-dioxid vázas megoldás ígérte a legmegfelelőbb megoldást.

A restauráció elkészülte alatt a páciens a labor által készített ideiglenes fogpótlást hordott (1.2. ábra).

A cirkóniumváz próbája után (1.3. ábra), Vita Easyshade (Vita Zahnfabrik, Bad Säckingen, 79704 Germany) készülék segítségével kiválasztottuk a megfelelő fogszínt, majd a váz leplezése után a híd beragasztásra került (1.4., 1.5. ábra)

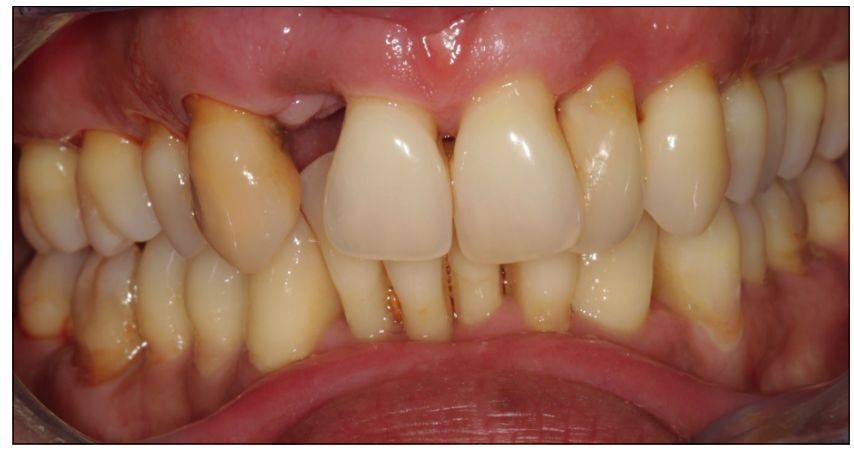

1.1. ábra: Kiindulási státusz a 12-es fog eltávolítása után

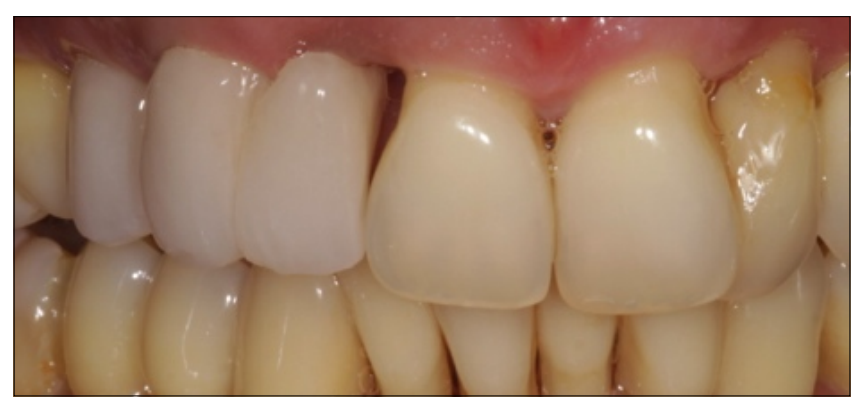

1.2. ábra: Labor által készített ideiglenes fogpótlás

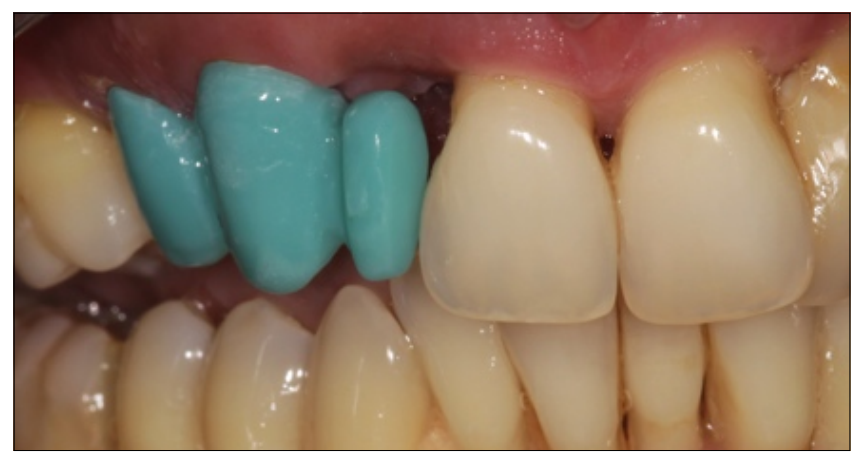

1.3. ábra: Viaszmintázat próbája

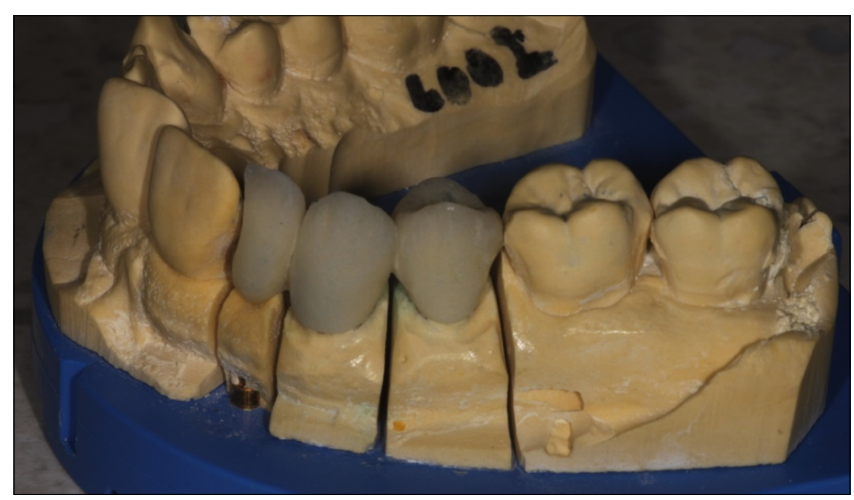

1.4. ábra: Nyerspróba mintán

\section{2. eset}

A 34 éves hölgy páciens, azzal a panasszal kereste fel klinikánkat, hogy a jobb felső egyes fogán lévő kemény-akrilát leplezésű korona esztétikai megjelenése nem megfelelő, szeretné lecserélni.

A 13-as fog 14 éve gyökérkezelt, panaszmentes, cseréje nem indokolt. A régi korona esztétikai hátrányai mellett túldimenzionált és gingivális irányba túlterjesztett volt, hosszú éveken keresztül krónikus gingivitiszt okozva (2.1. ábra). Ezért az első és legfontosabb teendő egy olyan ideiglenes korona készítése volt, amely nem irritálja a marginális parodonciumot. Az ideiglenes korona elkészítéséhez alsó-felső tanulmányi lenyomat alapján diagnosztikus felviaszolást készítettünk (2.2. ábra), majd az elkészült mintáról szilikon szituációs lenyo- 


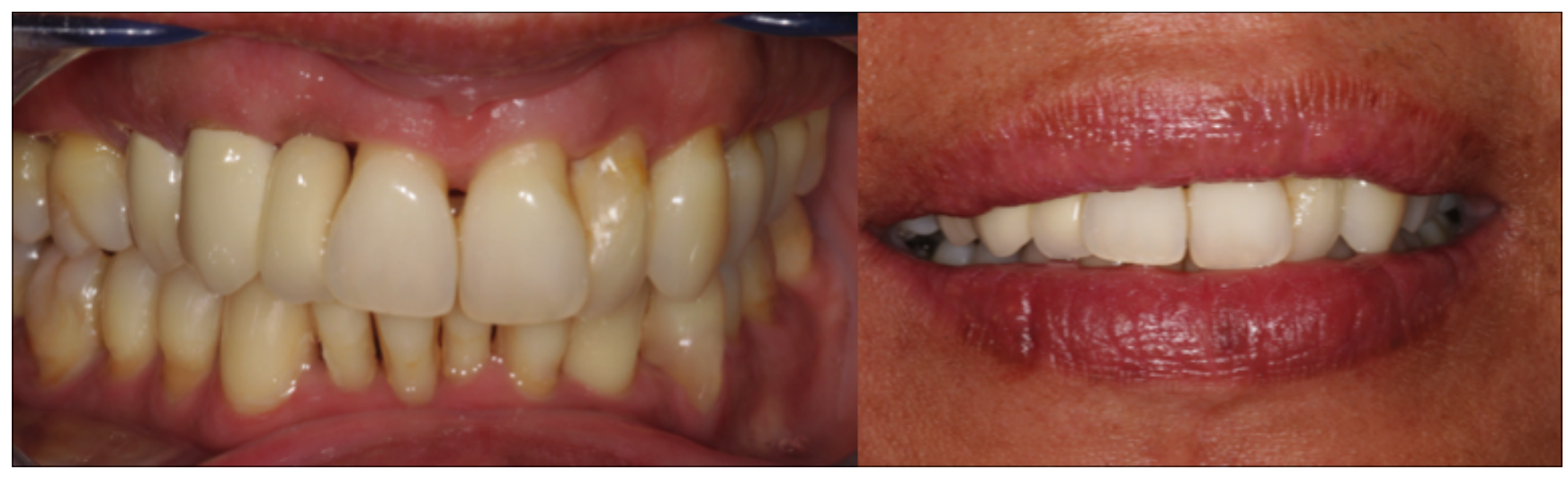

1.5. ábra: Kész fogpótlás

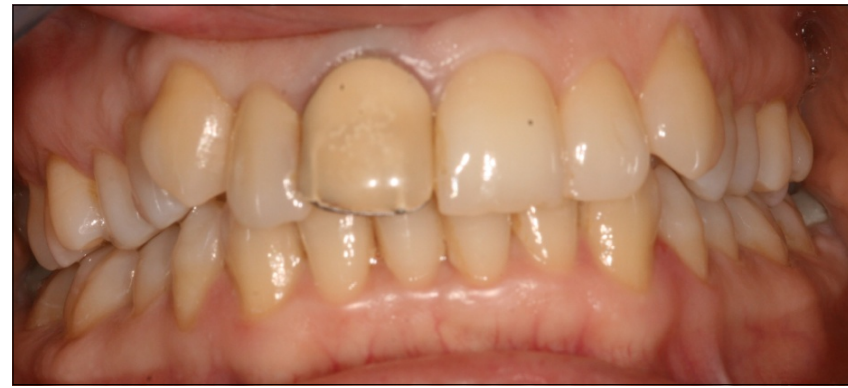

2.1. ábra: Kiindulási állapot

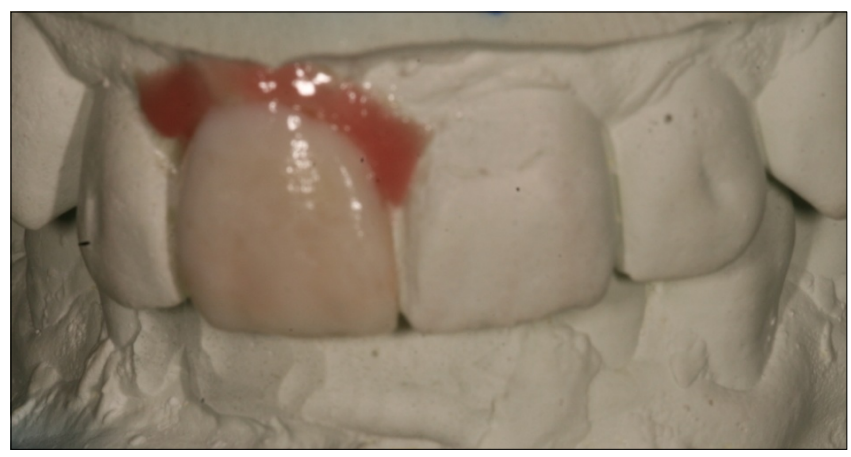

2.2. ábra: Diagnosztikus felviaszolás

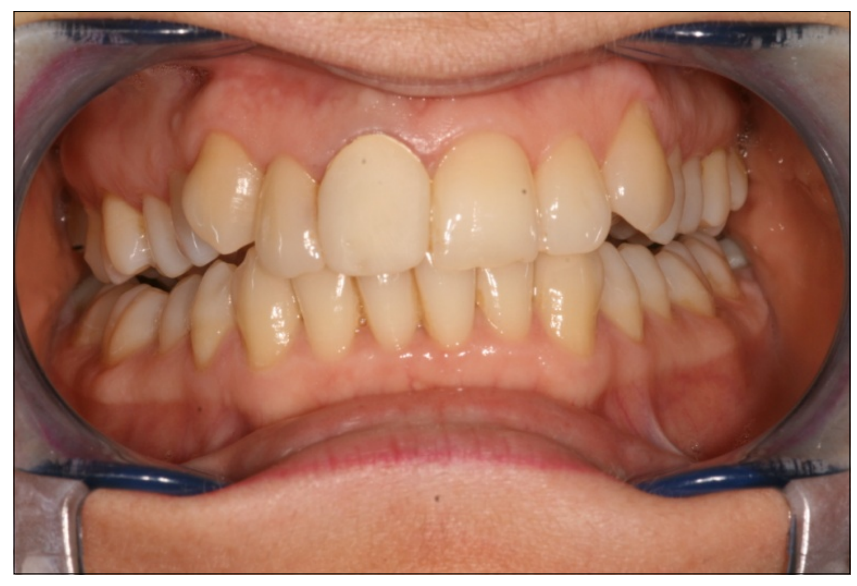

2.3. ábra: Ideiglenes korona

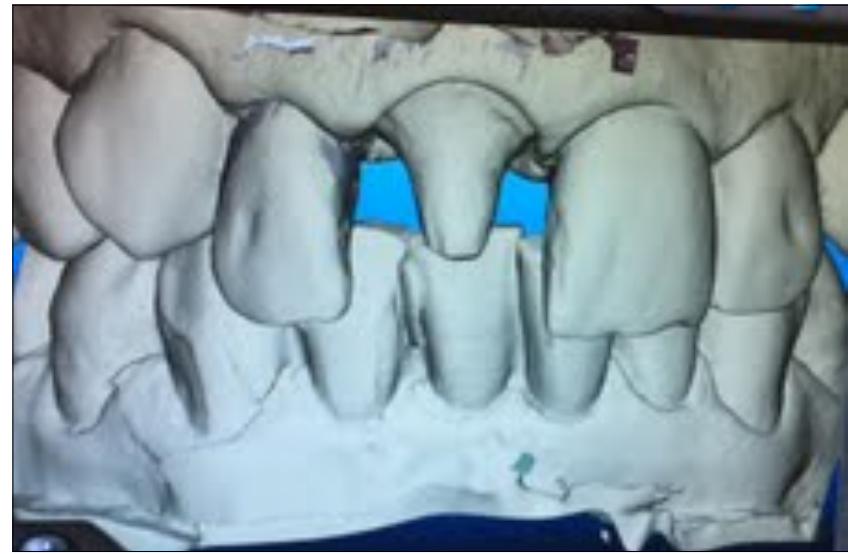

2.4. ábra: Digitális lenyomat készítése

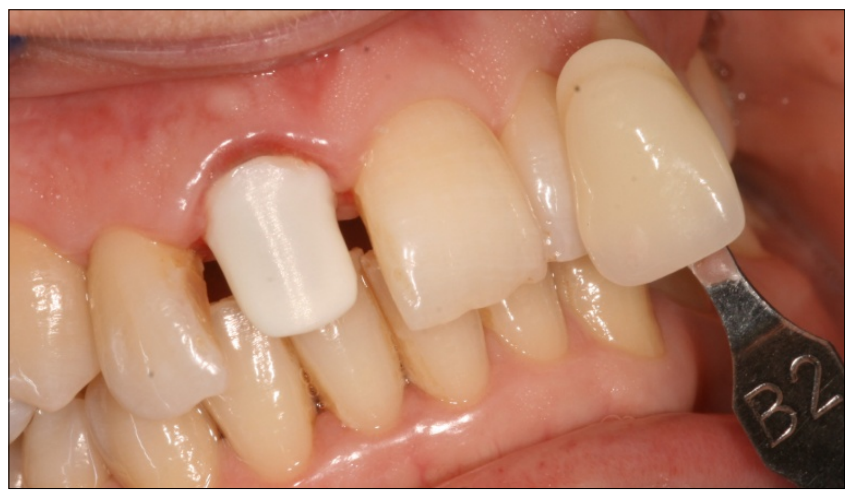

2.5. ábra: Cirkónium-dioxid váz próbája és fogszínválasztás

matot vettünk. Ennek alapján már Scutan módszerrel el lehetett készíteni az ideális méretű ideiglenes koronát (2.3. ábra).

A régi fogmú eltávolítása után a preparált fog klinikai koronájának háromnegyed részét szuvasnak találtuk, ezért a csonkkiegészítéshez üvegszál erősítésű adhezív gyári csapot alkalmaztunk. A paragingivális, legömbölyített vállal előkészített csonkról sulcustágítást követően intraorális scannerrel digitális lenyomatot vettünk (2.4. ábra) (iTero, Align Technology /San Jose, Kalifornia/). 


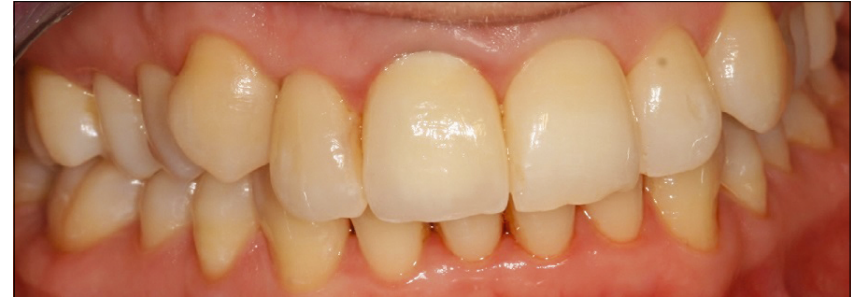

2.6. ábra: Kész korona átadása

A korona elkészültéig, a mechanikai irritációt megszüntetve, a parodoncium gyógyulásnak indult. A cirkóniumváz próbája után (2.5. ábra), Vita Easyshade készülék segítségével kiválasztottuk a megfelelő fogszínt, majd a váz leplezése után a korona becementezésre került (2.6. ábra).

A rövid távú kontroll során készült fotón jól látható, hogy az irritált marginális gingiva meggyógyult. Az elkészült korona a cirkónium-dioxid opak tulajdonságának megfelelően elfedi az elszíneződött gyökérkezelt fogat.

\section{3. eset}

Egy 35 éves férfi páciens azzal a kéréssel fordult hozzánk, hogy jobb felső kvadránsban lévő foghiányát szeretné pótoltatni. Elmondása szerint körülbelül 15 évvel ezelőtt vesztette el a fogait ezen a területen. Ez idő alatt a jobb alsó 6-os foga olyan mértékben elongálódott, hogy helyzete nem tette lehetővé egy felső laterálhíd készítését (3.1. ábra).

A páciens a fogszabályozó kezeléstől elzárkózott, ezért egyetlen megoldásként a 36-os fog nivellálása jöhetett szóba a fog devitalizálása nélkül.

Első lépésként a 36-os fogat a megfelelő magasságig dekoronáltuk, majd Scutan módszerrel ideiglenes koronát készítettünk. A páciens kérése az volt, hogy lehetőség szerint kerüljük el a gyökérkezelést, mely kérés nagyban megnehezítette a gyakorlati kivitelezést: körülbelül $1 \mathrm{~mm}$-t kellett volna még okkluzálisan elvenni a fémkerámia koronához, de ez már nem volt biztonságosan elvégezhető, így a következő kezelési terv mellett döntöttünk: a 36-os fogra cirkónium-dioxid vázas koronát készítünk, amire okkluzálisan csak egy nagyon vékony szinterelt kerámiaréteg kerül.

Kezelési tervünket az alábbi szempontok figyelembevételével hoztuk meg: a cirkónium dioxidnak kiváló a hőszigetelése; másrészt esztétikailag nem zavaró, ha nem anatomikus a rágófelszín; harmadrészt ezzel a megoldással körülbelül $1 \mathrm{~mm}$-t lehet nyerni vertikálisan, ami jelen esetben pont elég arra, hogy a bal felső kvadránsba elegendő helyet biztosítsunk egy kerámiával leplezett fémvázas híd számára. Mivel a bal felső bölcsességfog meziális felén, valószínúleg nehéz tisztíthatósága miatt, mély tasak volt megfigyelhető, illetve ebből kifolyólag enyhe fokban mozgatható volt, így a fogpótlásba nem vontuk be, később extrakcióra került.
A 36-os fogra elkészült korona becementezése után (3.2. ábra), a paragingivális, a felső állcsonton legömbölyített vállal előkészített csonkokról precíziós szituációs lenyomat alapján elkészült a lateralhíd váza. A váz kerámiával való leplezése (leplezett horgonykoronák: 23, 27 leplezett hézagfogak: 24, 25, 26) után (3.3. ábra) a felső restauráció is átadásra került (3.4., 3.5. ábra).

Míg az irodalom más telikerámia anyagokból csak front-restaurációk, illetve kisebb kiterjedésű, maximum háromtagú hidak készítését javasolja, addig a cirkóniumdioxid vázas restaurációk indikációs területe sokkal szélesebb. Viszonylag magas nyomási és torziós ellenállása miatt a moláris régióban is alkalmazható [14], illetve háromtagúnál hosszabb, vagy akár szabad végű hidak is biztonságosan készíthetők belőle [15]. A cirkónium-

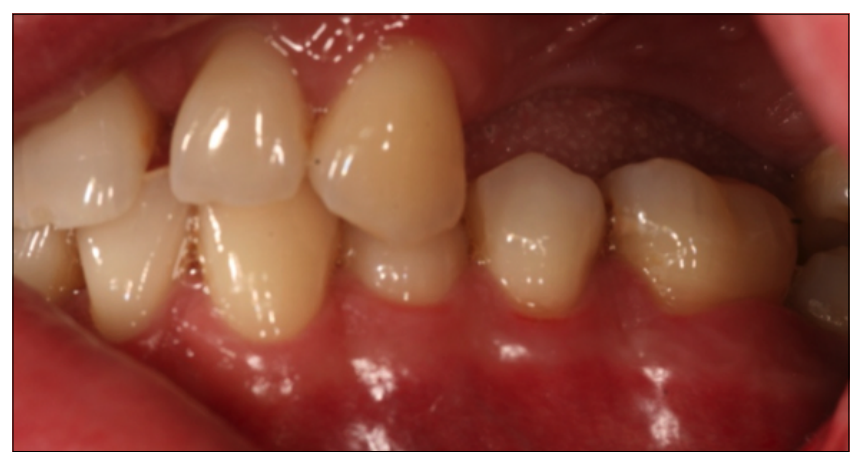

3.1. ábra: Kiindulási állapot

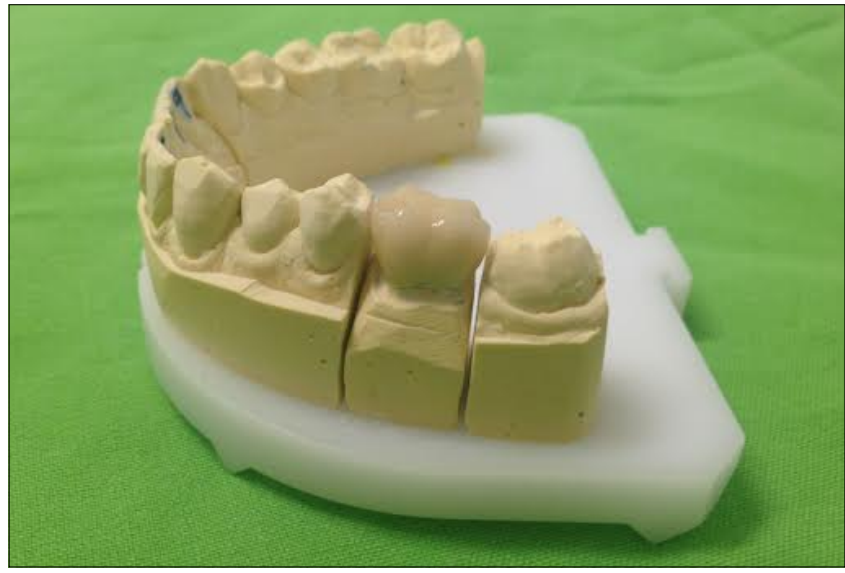

3.2. ábra: Elkészült cirkónium-dioxid vázas korona mintán

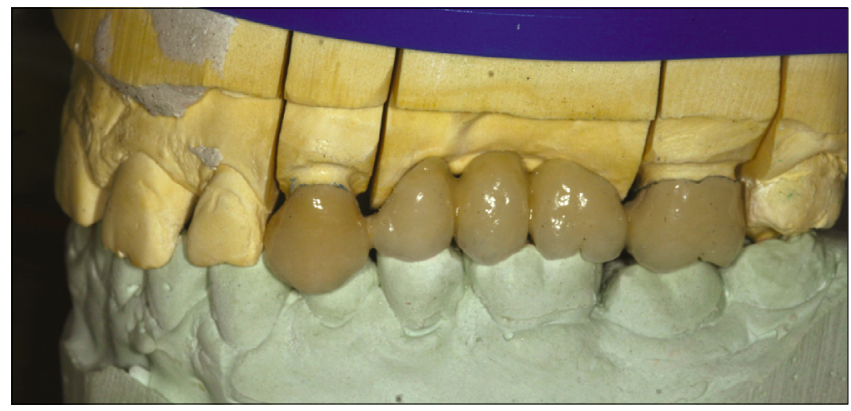

3.3. ábra: Az elkészült lateralhíd artikulátorban 
dioxid váz több színben elérhető, így igazítható a csonk színéhez, ez nagyban hozzájárul a magasabb esztétikai eredmény eléréséhez. Opacitásuk miatt elszíneződött, gyökérkezelt fogakra vagy akár fémcsapokra is esztétikus restauráció készíthető. Fémektől eltérő feldolgozási technológiája, a hideg frézelés nagyfokú precizitásra ad módot. Napjainkban tehát a mindennapi klinikai gyakorlatban a cirkónium-dioxid vázas fix restaurációk a részleges foghiányok pótlásában komoly alternatíváját képzik a klasszikus fémkerámia munkáknak. Alkalmazásuknál egyszerre használhatjuk ki a fémekhez hasonló kiváló mechanikai és előnyös optikai tulajdonságaikat.

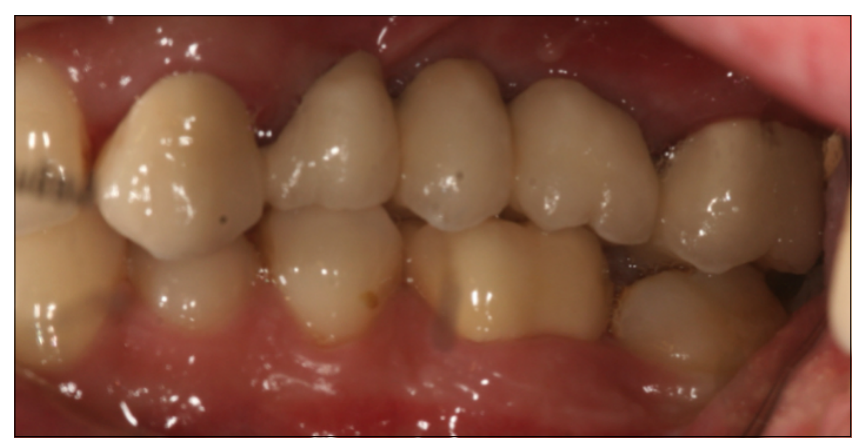

3.4. ábra: Becementezett alsó és felső fogművek

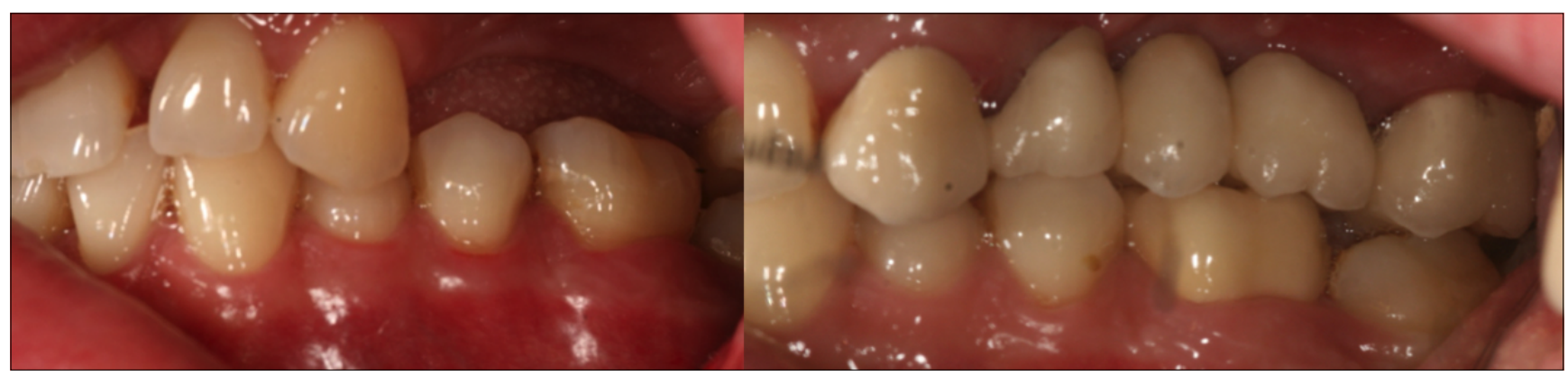

3.5. ábra: Előtte-utána

\section{Irodalom}

1. АвOUSHELIB MN: Fatigue and fracture resistance of zirconia crowns prepared with different finish line designs. Journal of prosthodontics: official journal of the American College of Prosthodontists 2012; 21(1): 22-27.

2. Ernst CP, Cohnen U, Stender E, Willershausen B: In vitro retentive strength of zirconium oxide ceramic crowns using different luting agents. The Journal of prosthetic dentistry 2005; 93(6): 551-558.

3. Gamborena I, Blatz MB: A Clinical Guide to Predictable Esthetics with Zirconium Oxide Ceramic Restorations. Quintessence of Dental Technology 2006; 29: 11-23.

4. Gargari M, Gloria F, Napoli E, Pujia AM: Zirconia: cementation of prosthetic restorations. Literature review. ORAL \& implantology 2010; 3(4): 25-29.

5. Larsson C, Vult von Steyern P, Sunzel B, Nilner K: All-ceramic twoto five-unit implant-supported reconstructions. A randomized, prospective clinical trial. Swedish dental journal 2006; 30(2): 45-53.

6. Luthy H, Filser F, Loeffel O, Schumacher M, Gauckler LJ, HamMERLE CH: Strength and reliability of four-unit all-ceramic posterior bridges. Dental materials: official publication of the Academy of Dental Materials 2005; 21(10): 930-937.
7. McLaren EA, Giordano R: Zirconia-Based Ceramics: Material Properties, Esthetics, and Layering Techniques of a New Veneering Porcelain, VM9. Quintessence of Dental Technology 2005; 28: 99-103.

8. Piconi C, Maccauro G: Zirconia as a ceramic biomaterial. Biomaterials 1999; 20(1): 1-25.

9. Piwowarczyk A, Ottl P, Lauer hC, Kuretzky T: A clinical report and overview of scientific studies and clinical procedures conducted on the 3M ESPE Lava All-Ceramic System. Journal of prosthodontics: official journal of the American College of Prosthodontists 2005; 14(1): 39-45.

10. Ротікет N, Chiche G, Finger IM. In vitro fracture strength of teeth restored with different all-ceramic crown systems. The Journal of prosthetic dentistry 2004; 92(5): 491-495.

11. Raigrodski AJ, Chiche GJ, Potiket N, Hochstedler JL, Mohamed SE, BILLIOT S, ET AL: The efficacy of posterior three-unit zirconiumoxide-based ceramic fixed partial dental prostheses: a prospective clinical pilot study. The Journal of prosthetic dentistry 2006; 96(4): 237-244.

12. Sailer I, Feher A, Filser F, Luthy H, Gauckler LJ, Scharer P, ET AL: Prospective clinical study of zirconia posterior fixed partial dentures: 3-year follow-up. Quintessence international 2006; 37(9): 685-693.

\section{Somfai D, Zsigmond Á, Károlyházy K, Kispélyi B, Hermann P}

\section{The clinical application of zirconium-dioxide-ceramics Case report}

Due to its outstanding physical, mechanical and esthetic properties, zirconium-dioxide is one of the most popular nonmetal denture, capable of surpassing PFM in most cases. The recent advances of CAD/CAM technology makes it a good alternitve. Here we show the usefulness of zirconium-dioxide in everyday dental practice through three case reports.

Keywords: zirconium-dioxide, esthetics, CAD/CAM, wax-up 